\title{
EFFECTIVE SERS SUBSTRATE OBTAINED BY AU DEPOSITION AT SILICA SURFACES THROUGH A TOP DOWN METHOD
}

\author{
A. Damin, P. Ivanchenko, M. Fabbiani, G. Martra \\ Department of Chemistry and NIS Centre, University of Turin, 7 Via P. Giuria, Turin, 10125, Italy \\ e-mail: alessandro.damin@unito.it \\ Submitted November 15, 2019 \\ Accepted May 08, 2020
}

Background: In the last years some of us developed methods for preparing, through simple synthesis protocols, gold nanoparticles supported on silica surfaces: in that cases, bottom-up approaches has been adopted (i.e. starting from $\mathrm{HAuCl}_{4}$ precursor) and high surface area silica (Aerosil 300) was chosen as support (together with controlled $\mathrm{pH}$ conditions), to facilitate Au dispersion. The obtained substrates showed the ability to enhance Raman signals of dosed molecules pyridine and bi-pyridine and/or of silanols species populating the silica surface. Following this idea, in this paper we will present results concerning surfaceenhanced Raman spectroscopy (SERS) activity of substrates obtained by a top-down technique (i.e. gold sputtering) which allowed depositing gold nanoparticles at surfaces of silica nanoparticles. Pyridine molecule has been then used as a probe molecule to estimate the SERS activity of the obtained substrates.

Objectives: The purpose of the work was to study the SERS activity of the prepared substrates through the estimation of limit of detection (LoD) of pyridine molecule dosed from solutions (benzene was used as solvent) with decreasing pyridine concentration.

Materials and methods: For the preparation of the samples AOX50 silica (Evonik Industries, surface area of $50 \mathrm{~m}^{2} / \mathrm{g}$ ) in form of pressed disk, a gold target and a K575X Turbo Sputter Coater (Quorum Technologies) were used. Methods applied: UV-Vis-NIR spectroscopy; HR-TEM microscopy; Raman spectroscopy.

Results: Prepared Au/AOX50 substrates with nominal Au thickness $10 \mathrm{~nm}$ were characterized by the UV-Vis spectroscopy and HR-TEM microscopy. They showed a relatively complex absorption profile extending to the NIR region. The substrates contained gold nanoparticles with diameter in the range of 2.0-3.5 nm. By using the $785 \mathrm{~nm}$ exciting laser line (suggested by the results coming from UV-Vis spectroscopy) for recording Raman spectra, it was possible to observe characteristic pyridine Raman signals by contacting $\mathrm{Au} / \mathrm{AOX} 50$ substrates with vapour phase of benzene solutions with pyridine concentration as low as $10^{-7} \mathrm{M}$ comprising LoD. This allowed us to estimate roughly an enhancement factor of $10^{8}$, as compared with 12.4 M pyridine dosed at naked AOX50 silica surface.

Conclusion: Through a top-down technique it was possible to prepare effective SERS substrates composed by $\mathrm{Au}$ nanoparticles dispersed at AOX50 silica surfaces. LoD for pyridine dosed from the vapour of its benzene solution appeared to be $10^{-7} \mathrm{M}$ and the SERS enhancement factor, using as a reference Raman spectra of $12.4 \mathrm{M}$ pyridine interacting with naked AOX50 silica, has been estimated to be approximately $10^{8}$.

KEY WORDS: SERS; gold nanoparticles; silica; sputtering.

\section{ЕФЕКТИВНА ПОВЕРХНЯ ДЛЯ SERS, ОТРИМАНА НАНЕСЕННЯМ ЗОЛОТА НА КРЕМНЕЗЕМ МЕТОДОМ «ЗВЕРХУ ВНИЗ»}

\author{
А. Дамін, П. Іванченко, М. Фаббіані, Дж. Мартра
}

Факультет хімії та Центр наноструктурованих інтерфейсів та поверхонь, Університет Турину, вул. П. Джурія, 7, Турин, 10125, Італія

Актуальність. Нещодавно один з нас розробив метод приготування золотих наночастинок на поверхні кремнезему: в цьому випадку було застосовано метод «знизу доверху» (а саме, починаючи із прекурсору $\mathrm{HAuCl}_{4}$ ), використовуючи діоксид кремнію із високою питомою площею поверхні (Аеросил А300) як основу (при контрольованому pH) для покращення дисперсії золота. Отримані матеріали продемонстрували здатність підсилювати раманівські сигнали адсорбованих молекул піридину та біпіридину та/або поверхневих силанолів. Слідуючи цій ідеї, дана робота демонструє результати стосовно активності субстратів для підсиленої поверхнею раманівської спектроскопії

(C) Damin A., Ivanchenko P., Fabbiani M., Martra G., 2020 
(surface-enhanced Raman spectroscopy, SERS), підготовлених методом «зверху вниз» (з розпиленням золота), який дозволяє осаджувати наночастинки золота на поверхні наночастинок діоксиду кремнію. Молекули піридину були використані як зонди для оцінки SERS активності отриманих субстратів.

Мета роботи. Метою даної роботи є вивчення SERS активності виготовлених субстратів шляхом визначення межі виявлення молекул піридину, нанесених із розчинів (розчинник - бензол) зі зниженням концентрації піридину.

Матеріали і методи. Для приготування зразків використовували діоксид кремнію АOX50 (Evonik Industries, питома поверхня $\left.50 \mathrm{~m}^{2} / \Gamma\right)$ у формі пресованих дисків, золоту мішень та розпилювач K575X Turbo Sputter Coater (Quorum Technologies). Використані методи: УФ- та видима спектроскопія, HR-TEM мікроскопія, Раманівська спектроскопія.

Результати. Приготовані субстрати Au/AOX50 (номінальна товщина золота 10 нм) були охарактеризовані за допомогою УФ- та видимої спектроскопії та HR-TEM мікроскопії. Вони продемонстрували відносно складний профіль поглинання, що простягається до ближнього IЧ діапазону. Субстрати складались із золотих наночастинок діаметром близько 2,0-3,5 нм. Використання для збудження лазеру на довжині хвилі 785 нм (обраної на основі даних УФвидимої спектроскопії) для реєстрації Раман-спектрів дозволило спостерігати Раман-сигнали, характерні для піридину, при контакті Au/AOX50 субстратів з паровою фазою розчину піридину у бензолі і концентрацією піридину до $10^{-7} \mathrm{M}$, що складало межу його виявлення. Це дозволило приблизно оцінити фактор підсилення (ФП), що становить близько $10^{8}$, у порівнянні $312,4 \mathrm{M}$ піридину, нанесеного на поверхню чистого АОХ50.

Висновки. Метод «зверху вниз» дозволив приготувати ефективні SERS субстрати, що складаються із наночастинок золота, диспергованих на поверхні кремнезему АОХ50. Межа виявлення піридину виявився $10^{-7} \mathrm{M}$ (при нанесенні з пари його розчину у бензолі), та ФП SERS був оцінений приблизно в $10^{8}$ (використовуючи як стандарт Раман-спектр 12,4 М піридину в контакті з поверхнею чистого АОХ50).

КЛЮЧОВI СЛОВА: SERS; золоті наночастинки; діоксид кремнію; розпилення.

\section{ЭФФЕКТИВНАЯ ПОДЛОЖКА ДЛЯ SERS, ПОЛУЧЕННАЯ НАНЕСЕНИЕМ ЗОЛОТА НА КРЕМНЕЗЕМ МЕТОДОМ «СВЕРХУ ВНИЗ»}

А. Дамин, П. Иванченко, М. Фаббиани, Дж. Мартра

Факультет химии и Центр наноструктурированых интерфейсов и поверхностей, Университет Турина, ул. П. Джурия, 7, Турин, 10125, Италия

Актуальность. Недавно один из нас разработал метод приготовления золотых наночастиц на поверхности кремнезема: в этом случае был применен метод «снизу вверх» (а именно, начиная с прекурсора $\mathrm{HAuCl}_{4}$ ), используя диоксид кремния с высокой удельной площадью (Аэросил А300) как основу (при контролированном $\mathrm{pH}$ ) для улучшения дисперсии золота. Полученные материалы продемонстрировали способность к усилению рамановских сигналов адсорбированных молекул пиридина и бипиридина и/или поверхностных силанолов. Следуя этой идее, данная работа демонстрирует результаты касательно активности субстратов для поверхностно-усиленной рамановской спектроскопии (surface-enhanced Raman spectroscopy, SERS), приготовленных методом «сверху вниз» (с распылением золота), который позволяет осаждать наночастицы золота на поверхности наночастиц диоксида кремния. Молекулы пиридина были использованы как зонды для оценки SERS активности полученных субстратов.

Цель работы. Целью данной работы является изучение SERS активности изготовленных субстратов путём определения предела обнаружения молекул пиридина, наносившихся из растворов (растворитель - бензол) с убывающей концентрацией пиридина.

Материалы и методы. Для приготовления образцов были использованы: диоксид кремния AOX50 (Evonik Industries, удельная площадь $50 \mathrm{~m}^{2} / \Gamma$ ) в форме прессованных дисков, золотая мишень и распылитель К575X Turbo Sputter Coater (Quorum Technologies). Использованные методы: УФ-видимая спектроскопия, HR-TEM микроскопия, Рамановская спектроскопия.

Результаты. Приготовленные субстраты Au/AOX50 (номинальная толщина золота 10 нм) были охарактеризованы с помощью УФ-видимой спектроскопии и HR-TEM микроскопии. Они продемонстрировали относительно сложный профиль поглощения вплоть до ближнего ИК диапазона. Субстраты содержали золотые наночастицы с диаметром около 2,0-3,5 нм. При использовании полосы возбуждения лазера 785 нм (выбранной на основании результатов УФвидимой спектроскопии) для записи Рамановских спектров было возможно наблюдать рамановские сигналы, характерные для пиридина, при контакте Аu/AOX50 субстратов с паровой фазой раствора пиридина в бензоле с концентрацией пиридина вплоть до $10^{-7} \mathrm{M}$, что составляло 
Effective SERS substrate obtained by Au deposition at silica surfaces...

предел его обнаружения. Это позволило приблизительно оценить фактор усиления (ФУ), как $10^{8}$ в сравнении с 12,4 М пиридина нанесенного на поверхность чистого АOХ50.

Выводы. Метод «сверху вниз» позволил приготовить эффективные SERS субстраты, состоящие из наночастиц золота, диспергированных на поверхности кремнезема АОХ50. Предел обнаружения пиридина оказался равным $10^{-7} \mathrm{M}$ (при нанесении из паров его раствора в бензоле), и ФУ SERS был оценен приблизительно в $10^{8}$ (используя как стандарт Раман-спектр 12,4 M пиридина в контакте с поверхностью чистого AOX50).

КЛЮЧОВЫЕ СЛОВА: SERS; золотые наночастицы; диоксид кремния, распыление.

Raman spectroscopy is a non-destructive spectroscopic technique finding an application in a wide variety of fields of investigation (catalysis, clinical and forensic chemistry, cultural heritage conservation and characterization, material science). Despite its potential great utility, such technique suffers from an intrinsic low sensitivity due to the physical phenomenon underlying it. Thus, it is hardly applicable to systems where the investigated species (the active site of a catalyst or a molecule of particular interest) is in low concentration. To increase sensitivity of Raman spectroscopy, resonance conditions can be adopted: in this case the use of an exciting laser line, falling in the electronic absorption of the studied species. This approach helps in the selective enhancement of signals coming from their vibrational features, making Raman spectroscopy a site(molecule)-selective technique too.

In the last years another approach strongly bound to nanotechnology knew a wide diffusion. This is based on the observation, made in the late $70 \mathrm{~s}-80 \mathrm{~s}$ of the past century, that when molecules interact with roughened (nanostructured) coinage metal surfaces, and suitable exciting laser lines are adopted, some of their Raman signals result to be enhanced of several order of magnitude $[1,2]$, thus allowing their identification even at very low concentration. Such a technique, nowadays well known as surface-enhanced Raman spectroscopy (SERS) can overcome the limitations of Raman spectroscopy, increasing its performance in fields of investigation heavily dominated by the "low concentration problem", such as those concerning bio-sensing [3-6], detection of bacteria [7], food analysis [8] and more in general analytical chemistry $[9,10]$ are.

Recently some of us developed methods for preparing, with simple synthesis protocols, gold nanoparticles supported on silica surfaces: in that cases, bottom-up approaches has been adopted (i.e. starting from $\mathrm{HAuCl}_{4}$ ) and high surface area silica (Aerosil300) was chosen as support (together with controlled $\mathrm{pH}$ conditions), to facilitate gold dispersion. The obtained substrates showed the ability to enhance Raman signals of dosed molecules (pyridine and bipyridine) and/or of silanols species populating the silica surface [11]. Following this idea, in this work we are presenting the results concerning SERS activity of substrates obtained by a top-down technique (i.e. gold sputtering) that allows depositing gold nanoparticles at silica surface. Pyridine (hereafter Py) molecule has been used as a probe and the enhancement ability of such substrates has been evaluated mainly through the evaluation of a limit of detection (LoD) in respect of the adopted probe molecule. An enhancement factor roughly estimated by comparing Raman spectra obtained on gold containing substrates with those recorded on bare silica nanoparticles contacted with Py will be presented too.

\section{MATERIALS AND METHODS}

Silica supports: parent silica supports for gold deposition were obtained by pressing ( 5 tons of applied pressure) AOX50 powder (Evonik Industries, $0.6 \mathrm{~g}$ ) in the form of disk of about $32 \mathrm{~mm}$ diameter. AOX50 system is a well-known type of silica, with Specific Surface Area (measured by BET method) equal to $50 \mathrm{~m}^{2} / \mathrm{g}$ and a silanol surface density of $1.4(\mathrm{SiOH}) / \mathrm{nm}^{2}$.

SERS substrates: substrates for SERS $\left(\mathrm{Au}_{\mathrm{x}} / \mathrm{AOX} 50, \mathrm{x}\right.$ is a nominal thickness, in $\mathrm{nm}$, of sputtered gold) were prepared by sputtering gold on the above described AOX50 supports 
with a K575X Turbo Sputter Coater (Quorum Technologies). Parameters of the instrumentation were set to achieve a nominal thickness of gold layers $\mathrm{x}$ to be equal to $10 \mathrm{~nm}$.

$U V$-Vis-NIR Diffuse Reflectance (DRUV-Vis-NIR) measurements: collection of DRUVVis-NIR spectra (1200-200 $\mathrm{nm}$ range) was performed with a Variant Cary 5000 spectrophotometer, equipped with a R928 PMT UV-Vis detector and a PbS NIR detector. Teflon pellet was used as reference for $100 \%$ of reflectance. Samples were investigated as such at ambient conditions.

HR-TEM measurements: the morphological characterization of the investigated systems was carried out with a JEOL JEM-3010-UHR transmission electron microscope $(300 \mathrm{kV}$ accelerating potential) and equipped with a $2 \mathrm{k} \times 2 \mathrm{k}$ Gatan US1000 CCD camera. In this case, samples were re-prepared by grinding the silica supports with subsequent gold sputtering for reaching the desired gold layer thickness.

Raman measurements: Samples for Raman measurements at ambient conditions were prepared by cutting small pieces $(5 \cdot 5 \cdot 1.1 \mathrm{~mm})$ of the investigated supports and placing them inside a $1 \mathrm{~cm}$ path UV cuvette (Helma, QS). Py (Sigma Aldrich, >99.8\%) has been dosed from the vapour phase as such or from benzene (Sigma Aldrich, $>99 \%$ ) solutions at variable concentrations by evaporating $10 \mu \mathrm{l}$ of liquid placed inside the UV cuvette before sealing it by tape. All Raman spectra were collected on the above described systems by employing an inVia Raman Microscope (Renishaw) and an exciting laser line falling at $785 \mathrm{~nm}$ (Renishaw Diode laser). Laser light was focused at the sample through a 20x ULWD MSPlan objective (Olympus, N.A. 0.4); back-scattered light (Rayleigh light removed through an edge filter) was analyzed by a $1200 \mathrm{1} / \mathrm{mm}$ grating and then sent to a CCD detector. Just $0.05 \%$ of the laser power reaching the sample $(80 \mathrm{~mW})$ was used in order to avoid its damage or/and modifications. Each presented Raman spectrum is the average of three spectra (collected on three different points of the investigated sample, the homogeneity of the sample being so verified) each one resulting as the sum of 20 acquisitions (in the $2350-100 \mathrm{~cm}^{-1}$ interval) of $20 \mathrm{~s}$ of duration.

\section{RESULTS AND DISCUSSION}

The obtained Au10nm/AOX50 substrates were characterized by means of DRUV-VisNIR and HR-TEM techniques (see Fig. 1, panels A and B respectively). As far as DRUV-VisNIR results are concerned, $\mathrm{Au}_{10 \mathrm{~nm}} / \mathrm{AOX} 50$ substrates showed a broad absorption in the 500$900 \mathrm{~nm}$ range (see curve $\mathrm{b}$ in Figure $1 \mathrm{~A}$ ), unlike the spectrum of bare AOX50 silica (see curve a, Fig. 1 A) and of bulk gold (curve c, Fig. 1 A). HR-TEM analysis (see Fig. 1 B for a representative micrograph of $\left.\mathrm{Au}_{10 \mathrm{~nm}} / \mathrm{AOX} 50\right)$ suggested that this absorption is mainly connected to the complex plasmonic features characterizing the observed Au nanoparticles (average diameters in the $2.0-3.5 \mathrm{~nm}$ range) aggregates.

Finally, the strong absorption observed in the Vis-NIR range showed also that the adoption of an exciting laser line falling at $785 \mathrm{~nm}$ (see dotted red line in Fig. 1 A) to record Raman spectra should be a good choice, in order to obtain a reasonable enhancement towards the adopted probe molecule.

Raman spectra of $\mathrm{Au}_{10 \mathrm{~nm}} / \mathrm{AOX} 50$ contacted with vapour phase of Py/benzene solutions (with Py varying in the $12.4-1 \times 10^{-7} \mathrm{M}$ concentration range) where collected as described in Raman measurements Section; the results are reported in Fig. 2. Pure Py (12.4 M) dosed in such conditions, results in two well-resolved signals, located at 1040 and $1015 \mathrm{~cm}^{-1}$, respectively. On the basis of literature data [12], they are can be assigned to $v_{8}$ and $v_{9}$, which in pure liquid Py fall respectively at 1031 and $993 \mathrm{~cm}^{-1}$ [13]. The observed blue-shift (and the change in the intensity ratio between the two signals too) with respect to the liquid phase is an evidence of a direct interaction of Py with Au atoms at the surface of gold nanoparticles [14]. 
No liquid or liquid-like Py is detectable in such conditions, neither when pure Py (12.4 M) is dosed. By following $v_{9}$ along Raman spectra recorded at decreasing Py concentrations (see solid lines of Fig. 2 A, from top to bottom), it clearly emerges that Py LoD, under such conditions, can be fixed at a concentration as low as $10^{-7} \mathrm{M}$. Finally, when comparing the intensity of $v_{9}$ peak taken at $10^{-7} \mathrm{M}$ with that recorded at the same conditions on bare AOX50 contacted with $12.4 \mathrm{M}$ Py (see black solid line in Fig. $2 \mathrm{~B}$ ), one can estimate a SERS analytical enhancement factor [15] of Py at $\mathrm{Au}_{10 \mathrm{~nm}} / \mathrm{AOX} 50$ substrate of about $10^{8}$, suggesting a remarkable SERS activity of substrates obtained with the above described protocol.
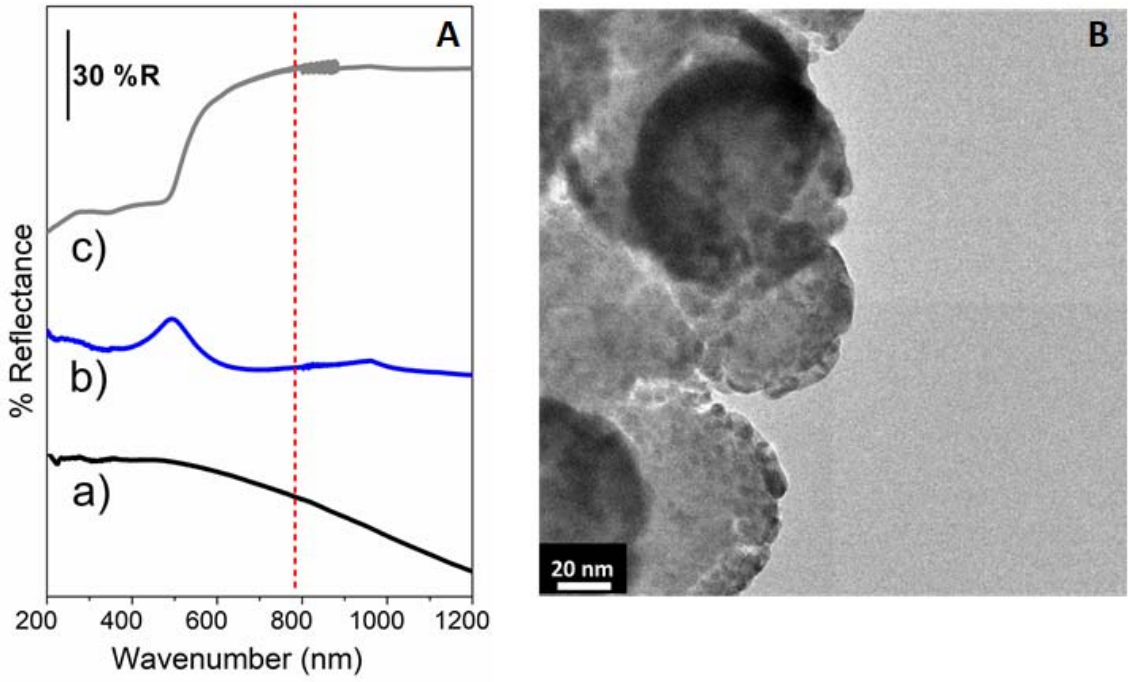

Fig. 1. A: DRUV-Vis-NIR recorded respectively on a) AOX50 (black line), b) $\mathrm{Au}_{10 \mathrm{~nm}} / \mathrm{AOX} 50$ (blue line), and c) bulk $\mathrm{Au}$ (grey line). B: HR-TEM image taken on $\mathrm{Au}_{10 \mathrm{~nm}} / \mathrm{AOX} 50$ substrate.
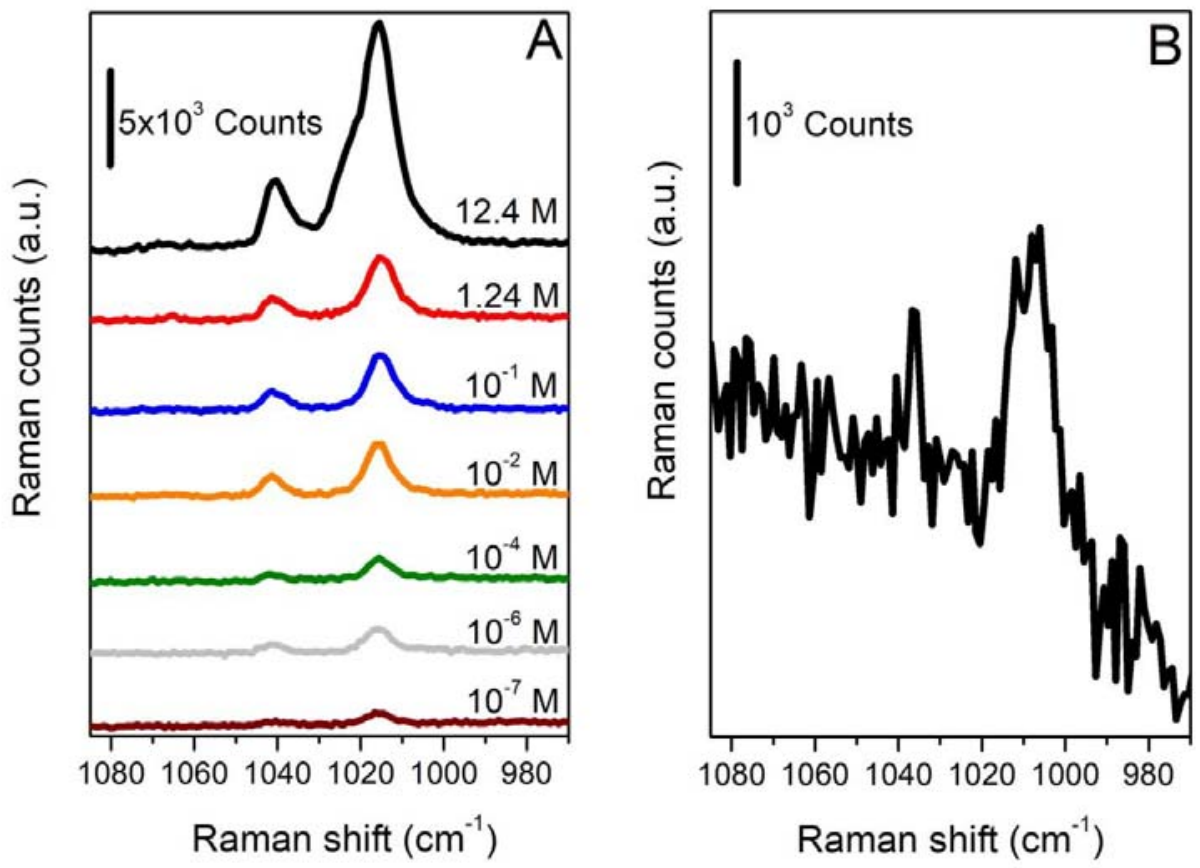

Fig. 2. Raman spectra recorded with $785 \mathrm{~nm}$ exciting laser line on: A - $\mathrm{Au}_{10 \mathrm{~nm}} / \mathrm{AOX} 50$ contacted with solutions at variable Py concentration in the $12.4 \times 10^{-7} \mathrm{M}$ range and B - AOX50 contacted with 12.4 M Py.

\section{CONCLUSIONS}

Through a top-down technique it was possible to prepare effective SERS substrates composed by Au nanoparticles dispersed at AOX50 silica surfaces. LoD of pyridine resulted 
to be $10^{-7} \mathrm{M}$ concentration (when dosed from vapour phase of benzene solutions) and the analytical enhancement factor (using as a reference Raman spectra of $12.4 \mathrm{M}$ pyridine interacting with bare AOX50 silica) has been estimated to be approximately $10^{8}$.

\section{ACKNOWLEDGMENT}

This work has been supported by NATO SPS project n. G5291 "A Novel Method for the Detection of Biohazards".

\section{CONFLICT OF INTEREST}

The authors report that there is no conflict of interest.
A. Damin (iD https://orcid.org/0000-0002-1110-0993
P. Ivanchenko (D) https://orcid.org/0000-0003-2280-0773
M. Fabbiani (iD https://orcid.org/0000-0002-9094-0279
G. Martra (iD https://orcid.org/0000-0002-8012-5342

\section{REFERENCES}

1. Albrecht MG, Creighton JA Anomalously intense Raman spectra of pyridine at a silver electrode. J. Am. Chem. Soc. 1977;99(15):5215-17. https://doi.org/10.1021/ja00457a071

2. Creighton J.A., Cristopher GB, Albrecht MG. Plasma resonance enhancement of Raman scattering by pyridine adsorbed on silver or gold sol particles of size comparable to the excitation wavelength. J. Chem. Soc., Faraday Trans. 2: Molecular and Chemical Physics 1979;75:790-8. https://doi.org/10.1039/F29797500790

3. Kneipp K, Kneipp H, Itzkan I, Dasari RR, Feld MS. Surface-enhanced Raman scattering and biophysics. J. Phys.: Condens. Matter 2002;14(18):R597-R624. http://stacks.iop.org/cm/14/R597

4. Kneipp J, Wittig B, Bohr H, Kneipp K. Surface-enhanced Raman scattering: a new optical probe in molecular biophysics and biomedicine. Theor. Chem. Acc. 2010;125(3-6):319-27. https://doi.org/10.1007/s00214-009-0665-2

5. Liu JJ, Jalali M, Mahshid S, Wachsmann-Hogiu S. Are plasmonic optical biosensors ready for use in pointof-need applications? Analyst. 2020;145(2):364-84. https://doi.org/10.1039/C9AN02149C

6. Wang HX, Zhao YW, Li Z, Liu BS, Zhang D. Development and Application of Aptamer-Based SurfaceEnhanced Raman Spectroscopy Sensors in Quantitative Analysis and Biotherapy. Sensors (Basel). 2019 Sep 3;19(17):3806. https://doi.org/10.3390/s19173806

7. Wang KD, Li SM, Petersen M, Wang S, Lu XN. Detection and Characterization of Antibiotic-Resistant Bacteria Using Surface-Enhanced Raman Spectroscopy. Nanomaterials. 2018;8(10):762. https://doi.org/10.3390/nano8100762

8. Alyami A, Quinn AJ, Iacopino D. Flexible and transparent Surface Enhanced Raman Scattering (SERS)Active Ag NPs/PDMS composites for in-situ detection of food contaminants. Talanta. 2019;201:58-64. https://doi.org/10.1016/j.talanta.2019.03.115

9. Restaino SM, White IM. A critical review of flexible and porous SERS sensors for analytical chemistry at the point-of-sample. Analytica Chimica Acta. 2019;1060:17-29. https://doi.org/10.1016/j.aca.2018.11.057

10. Bell SEJ, Charron G, Cortes E, Kneipp J, de la Chapelle ML, Langer J, et al. Towards Reliable and Quantitative Surface-Enhanced Raman Scattering (SERS): From Key Parameters to Good Analytical Practice. Angew. Chem.-Int. Ed. 2020;59(14):5454-62. https://doi.org/10.1002/anie.201908154

11. Budnyk AP, Damin A, Agostini G, Zecchina A. Gold nanoparticle aggregates immobilized on high surface area silica substrate for efficient and clean SERS applications. J. Phys. Chem. C 2010;114(9):3857-32. https://doi.org/10.1021/ip9112816

12. Pockrand I, Otto A. Coverage dependence of Raman scattering from pyridine adsorbed to silver/vacuum interfaces. Solid State Commun. 1980;35(11):861-5. https://doi.org/10.1016/0038-1098(80)91040-6

13. Kline $\mathrm{CH}$, Turkevich J. The vibrational spectrum of pyridine and the thermodynamic properties of pyridine vapors. J. Chem. Phys. 1944;12(7):300-9. https://doi.org/10.1063/1.1723943

14. Wu DY, Ren B, Jiang YX, Xu X, Tian ZQ. Density functional study and normal mode analysis of the bindings and vibrational frequency shifts of the pyridine- $\mathrm{M}\left(\mathrm{M}=\mathrm{Cu}, \mathrm{Ag}, \mathrm{Au}, \mathrm{Cu}^{+}, \mathrm{Ag}^{+}, \mathrm{Au}^{+}\right.$, and $\left.\mathrm{Pt}\right)$ complexes. J. Phys. Chem. A. 2002;106(39):9042-52. https://doi.org/10.1021/jp025970i

15. Le Ru EC, Blackie E, Meyer M, Etchegoin PG. Surface Enhanced Raman Scattering Factors: A comprehensive study. J. Phys. Chem. C. 2007;111(37):13794-803. https://doi.org/10.1021/jp0687908 